\title{
KELAYAKAN EKONOMI DAN LINGKUNGAN KEGIATAN PERTAMBANGAN RAKYAT DI KABUPATEN SLEMAN
}

\author{
Farida Afriani Astuti, Andi Sungkowo \\ Program Studi Teknik Lingkungan, Fakultas Teknologi Mineral, UPN "Veteran” Yogyakarta \\ Jl. SWK 104 Condongcatur Yogyakarta 55285 \\ e-mail : faridaafriani.astuti@gmail.com, andi.sungkowo@yahoo.com
}

\begin{abstract}
Abstrak
Kabupaten Sleman memiliki 19 titik lokasi penambangan rakyat yang belum memiliki ijin dari pemerintah. Kegiatan penambangan menghasilkan dampak positif dan negatif bagi lingkungan. Oleh karena itu perlu dilakukan penelitian mengenai kelayakan ekonomi dan lingkungan sebagai dasar untuk memberikan ijin bagi kegiatan pertambangan rakyat tersebut. Penentuan kelayakan ekonomi dan lingkungan menggunakan metode pengharkatan. Kelayakan ekonomi kegiatan penambangan menggunakan 3 parameter sebagai dasar evaluasi, baik untuk penambangan di bukit maupun di sungai. Parameter kegiatan penambangan di bukit adalah umur tambang, potensi pasar dan pemanfaatan bahan galian, dan benefit cost ratio (BCR). Sedangkan parameter kegiatan penambangan di sungai adalah perbandingan cadangan terhadap penggunaan bahan galian (PCPBG), potensi pasar dan pemanfaatan bahan galian, dan benefit cost ratio (BCR). Adapun parameter kelayakan lingkungan adalah jenis dampak yang dihasilkan dari kegiatan penambangan, yaitu Dampak Penting Hipotetik (DPH), Dampak Tidak Penting Hipotetik 1 (DTPH 1), dan Dampak Tidak Penting Hipotetik 2 (DTPH 2). Hasil penelitian menunjukkan bahwa dari aspek kelayakan ekonomi terdapat 10 titik lokasi tidak layak, 5 titik lokasi kurang layak, dan 4 titik lokasi layak. Sedangkan dari aspek kelayakan lingkungan terdapat 12 titik lokasi tidak layak, 4 titik lokasi kurang layak, dan 3 titik lokasi layak.
\end{abstract}

Kata Kunci: Kelayakan Ekonomi, Kelayakan Lingkungan, Pertambangan Rakyat

\begin{abstract}
Sleman Regency had 19 locations of local mining activities. Those locations do not have permission from the government. Mining activities has positive and negative effects for the environment. Therefore, it is necessary to analyze the economics and environmental feasibility as a basis to give permission to the local mining activities. The economic and environmental feasibility were determinedby scoring method. The economic viability was assessed by three parameters for evaluation both in the hills and the river.The parameters for mining activities in the hills were the lifetime of mining site, the market potential and utilization of minerals, and benefit cost ratio (BCR). While the parameters for mining activities on the river were the ratio of reserves and utilization minerals, the market potential and utilization minerals, and benefit cost ratio $(B C R)$. The environmental feasibility parameter was the type of impacts from mining operationssuch as hypothetical significant impact, hypothetical insignificant impact 1, and hypothetical insignificant impact 2. The results showed that economic feasibility had 10 points location were not feasible, 5 points location wereless feasible, and 4 points locationwere feasible. However, the results of the environmental feasibility had 12 points location were not feasible, 4 points location wereless feasible, and 3 points location were feasible.
\end{abstract}

\section{PENDAHULUAN}

Kabupaten Sleman sebagai salah satu kabupaten di Provinsi Daerah Istimewa Yogyakarta memiliki beberapa wilayah pertambangan rakyat. Pertambangan rakyat tersebut berupa tambang breksi, lempung dan pasir. Kegiatan pertambangan rakyat tersebar dibeberapa wilayah yang ada di Kabupaten Sleman. Adapun lokasi penambangan rakyat dapat dilihat pada Tabel 1. Berdasarkan Tabel 1. terdapat 19 kegiatan penambangan rakyat yang masih aktif dan menjadi fokus penelitian bagi penulis. Kegiatan pertambangan rakyat memberikan dampak positif dan negatif bagi 
lingkungan sekitar (Larasati, et al., 2012). Dengan adanya dampak tersebut maka penting sekali untuk dilakukan sebuah kajian tentang kelayakan ekonomi dan lingkungan kegiatan tambang tersebut, sama halnya dengan kelayakan ekonomi suatu suatu kegiatan industry (Astuti, 2016).

Tabel 1. Lokasi dan Kesampaian daerah kegiatan Penambangan Rakyat di Kab.Sleman

\begin{tabular}{|c|c|c|c|c|c|c|}
\hline \multirow[b]{2}{*}{ No } & \multirow[b]{2}{*}{$\begin{array}{c}\text { Lokasi Penambangan } \\
\text { (Dusun, Desa, Kecamatan) }\end{array}$} & \multirow[b]{2}{*}{ Koordinat } & \multicolumn{2}{|c|}{ Kesampaian lokasi } & \multicolumn{2}{|l|}{ Keterangan } \\
\hline & & & $\begin{array}{l}\text { Kota } \\
\text { Yogyakarta }\end{array}$ & Pusat Kab. & Jenis Tambang & $\begin{array}{c}\text { Titik } \\
\text { Loka } \\
\text { si }\end{array}$ \\
\hline 1 & Jogotirto , Jogotirto , Berbah & $\begin{array}{l}X: 441981 \\
Y: 9136616\end{array}$ & $14.9145 \mathrm{~km}$ & $19.982 \mathrm{~km}$ & Breksi tuff & 21 \\
\hline 2 & $\begin{array}{l}\text { Dlingosari, Wukirharjo, } \\
\text { Prambanan }\end{array}$ & $\begin{array}{l}X: 447935 \\
Y: 913645\end{array}$ & $24.4875 \mathrm{~km}$ & $28.9594 \mathrm{~km}$ & Breksi tuff & 1 \\
\hline 3 & Kerabat, Tamanmartani, Kalasan & $\begin{array}{l}X: 442883 \\
Y: 9146821\end{array}$ & $20.6574 \mathrm{~km}$ & $15.8297 \mathrm{~km}$ & Pasir & 6 \\
\hline & Kebon, Tamanmartani, Kalasan & $\begin{array}{l}X: 443183 \\
Y: 9145453\end{array}$ & $18.2851 \mathrm{~km}$ & $16.3039 \mathrm{~km}$ & Pasir & 8 \\
\hline & $\begin{array}{l}\text { Kepurun, Tamanmartani, } \\
\text { Kalasan }\end{array}$ & $\begin{array}{l}X: 443136 \\
Y: 9144470\end{array}$ & $18.417 \mathrm{~km}$ & $16.4764 \mathrm{~km}$ & Pasir & 9 \\
\hline & Kenaji, Tamanmartani, Kalasan & $\begin{array}{l}X: 443083 \\
Y: 9145232\end{array}$ & $19.8537 \mathrm{~km}$ & $16.3806 \mathrm{~km}$ & Pasir & 11 \\
\hline 4 & Balong, Donoharjo, Ngaglik & $\begin{array}{l}X: 433159 \\
Y: 9150784\end{array}$ & $15.0538 \mathrm{~km}$ & $6.86518 \mathrm{~km}$ & Pasir & 72 \\
\hline & Jaban, Sariharjo, Ngaglik & $\begin{array}{l}X: 432754 \\
\text { Y: } 9147593\end{array}$ & $11.1246 \mathrm{~km}$ & $3.78616 \mathrm{~km}$ & Pasir & 73 \\
\hline & $\begin{array}{l}\text { Wonosobo, Sardonoharjo, } \\
\text { Ngaglik }\end{array}$ & $\begin{array}{l}X:, 433756 \\
\text { Y: } 9149442\end{array}$ & $13.6885 \mathrm{~km}$ & $6.5098 \mathrm{~km}$ & Pasir & 74 \\
\hline 5 & $\begin{array}{l}\text { Klarangan, Hargobinangun, } \\
\text { Pakem }\end{array}$ & $\begin{array}{l}X: 435592 \\
Y: 9159103\end{array}$ & $22.7584 \mathrm{~km}$ & $16.0773 \mathrm{~km}$ & Pasir & 50 \\
\hline & $\begin{array}{l}\text { Glondong, Purwobinangun, } \\
\text { Pakem }\end{array}$ & $\begin{array}{l}X: 433362 \\
Y: 9152681\end{array}$ & $16.552 \mathrm{~km}$ & $9.36634 \mathrm{~km}$ & Pasir & 51 \\
\hline 6 & Mesen, Banyurejo, Tempel & $\begin{array}{l}X: 440682 \\
Y: 9149707\end{array}$ & $19.2211 \mathrm{~km}$ & $12.636 \mathrm{~km}$ & Pasir & 28 \\
\hline 7 & Pare dua, Sidorejo, Godean & $\begin{array}{l}X: 420928 \\
Y: 9142729\end{array}$ & $17.9357 \mathrm{~km}$ & $13.3996 \mathrm{~km}$ & $\begin{array}{l}\text { Pelapukan diorite } \\
\text { dan batu lempung }\end{array}$ & 16 \\
\hline & Pare tiga, Sidorejo, Godean & $\begin{array}{l}X: 420928 \\
Y: 9142729\end{array}$ & $17.9531 \mathrm{~km}$ & $13.3996 \mathrm{~km}$ & Batu lempung & 17 \\
\hline & Kwagon, Sidorejo, Godean & $\begin{array}{l}X: 420936 \\
Y: 9141445\end{array}$ & $11.3388 \mathrm{~km}$ & $13.6 \mathrm{~km}$ & $\begin{array}{l}\text { Pelapukan diorite } \\
\text { dan batu lempung }\end{array}$ & 18 \\
\hline 8 & Lagenan, Margoluwih, Seyegan & $\begin{array}{l}X: 420464 \\
Y: 9144388\end{array}$ & $16.0535 \mathrm{~km}$ & $12.6013 \mathrm{~km}$ & $\begin{array}{l}\text { Pelapukan diorite } \\
\text { dan batulempung }\end{array}$ & 19 \\
\hline & Pandekan, Margodadi, Seyegan & $\begin{array}{l}X: 421125 \\
Y: 9143318\end{array}$ & $17.9425 \mathrm{~km}$ & $13.3996 \mathrm{~km}$ & $\begin{array}{l}\text { Pelapukan diorite } \\
\text { dan batulempung }\end{array}$ & 15 \\
\hline 9 & $\begin{array}{l}\text { Ngentak, Sindomartani, } \\
\text { Ngemplak }\end{array}$ & $\begin{array}{l}X: 442378 \\
Y: 9147382\end{array}$ & $20.9574 \mathrm{~km}$ & $15.7997 \mathrm{~km}$ & Pasir & 57 \\
\hline & $\begin{array}{l}\text { Kalibulus, Sindomartani, } \\
\text { Ngemplak }\end{array}$ & $\begin{array}{l}X: 441919 \\
Y: 9149054\end{array}$ & $20.0585 \mathrm{~km}$ & $15.018 \mathrm{~km}$ & Pasir & 62 \\
\hline
\end{tabular}

Sumber: Dinas Pertambangan Kabupaten Sleman, (2000)

Semua lokasi (19 titik lokasi) kegiatan pertambangan belum mendapatkan ijin dari pemerintah (Ijin Pertambangan Rakyat atau IPR) sampai saat ini. Berdasarkan Peraturan Gubernur Nomor 110 Tahun 2015 tentang pelaksanaan izin usaha pertambangan rakyat menjelaskan bahwa IPR diberikan setelah ditetapkan Wilayah Pertambangan Rakyat (WPR) oleh menteri ESDM bersamaan dengan 
berlakunya UU No 23 Tahun 2014. Berawal dari kondisi tersebut maka penulis tertarik untuk melakukan kajian mengenai kelayakan ekonomi dan lingkungan dari kegiatan pertambangan rakyat. Dengan hasil kajian ini diharapkan dapat memberikan usulan atau masukan bagi pemerintah untuk memberikan ijin atau tidak terhadap kegiatan pertambangan rakyat yang ada di Kabupaten Sleman.

\section{METODOLOGI PENELITIAN}

\subsection{Evaluasi Kelayakan Ekonomi}

Kelayakan ekonomi dibagi menjadi 2 bagian, yaitu kelayakan ekonomi untuk kegiatan penambangan di bukit dan di sungai (Fauzi, 2004). Kelayakan ekonomi kegiatan penambangan menggunakan 3 parameter sebagai dasar evaluasi. Parameter kegiatan penambangan di bukit adalah umur tambang, potensi pasar dan pemanfaatan bahan galian, dan benefit cost ratio (BCR). Sedangkan parameter kegiatan penambangan di sungai adalah perbandingan cadangan terhadap penggunaan bahan galian (PCPBG) potensi pasar dan pemanfaatan bahan galian, dan benefit cost ratio $(\mathrm{BCR})$.

\section{a. PCPBG dan Umur Tambang}

$$
\begin{aligned}
& P C P B G=\frac{\text { Cadangan Terukur }(\mathrm{m} 3)}{\text { Produksi }(\mathrm{m} 3)} \\
& U T=\frac{\text { Cadangan Terukur }(\mathrm{m} 3)}{\text { Produksi }\left(\frac{\mathrm{m} 3}{\mathrm{th}}\right)}
\end{aligned}
$$

Perhitungan PCPBG menunjukkan bahwa semakin besar hasil perbandingan maka kegiatan penambangan masih dapat berlanjut untuk menghasilkan manfaat untuk masyarakat dan masih mampu untuk memenuhi permintaan bahan galian. Sedangkan hasil perhitungan umur tambang menunjukkan bahwa semakin panjang umur tambang maka kegiatan penambangan masih dapat berlanjut untuk menghasilkan manfaat meskipun dengan semakin panjang umur tambang juga akan meningkatkan biaya kegiatan penambangan. Akan tetapi dengan umur tambang yang panjang diharapkan dapat menutupi biaya kegiatan yang ditimbulkan. Dari dasar analisa tersebut maka dapat dibuat harkat untuk klasifikasi PCPBG dan Umur Tambang. Semakin besar hasil perbandingan maka diberi harkat 3 (tiga) dan semakin kecil hasil perbandingan diberi harkat 1 (satu). 


\section{b. Potensi Pasar dan Pemanfaatan Bahan Galiam}

Analisa kelayakan ekonomi perlu memberikan gambaran proyeksi permintaan dan pemanfaatan bahan galian dimasa yang akan datang. Dengan demikian parameter potensi pasar dan pemanfaatan bahan galian digunakan untuk memberikan gambaran tentang perkembangan pasar apakah masih berpotensi atau tidak untuk menghasilkan bahan galian dan dapat dimanfaatkan oleh masyarakat ataupun pengguna bahan galian. Dari dasar analisa tersebut maka dapat dibuat harkat untuk klasifikasi potensi pasar dan pemanfaatan bahan galian (Noor, 2006). Semakin tinggi permintaan dan manfaat bahan galian oleh pengguna maka perkembangan pasar dikatakan berpotensi tinggi dan diberi harkat 3 (tiga) sedangkan jika permintaan dan pemanfaatan bahan galian rendah maka perkembangan pasar dikatakan berpotensi rendah dan diberi harkat 1 (satu).

\section{c. Benefit Cost Ratio (BCR)}

Yaitu salah satu metode analisis kelayakan ekonomi kegiatan penambangan dengan membandingkan total manfaat/benefit kegiatan pertambangan terhadap total biaya/cost kegiatan pertambangan. Apabila nilai BCR $>1$, memiliki arti bahwa total manfaat tambang lebih besar dari total biaya yang ditimbulkan dan diberi harkat 3 (tiga) sedangkan jika nilai BCR $<1$, memiliki arti bahwa total biaya lebih besar dari total manfaat tambang yang ditimbulkan dan diberi harkat 1 (satu).

$$
\text { BCR }=\frac{\text { Total Manfaat }}{\text { Total Biaya }}
$$

\subsubsection{Klasifikasi Kelayakan Ekonomi}

Langkah selanjutnya setelah memperoleh harkat adalah menentukan klasifikasi untuk mendapatkan kriteria kelayakan ekonomi dari total skor. Adapun hasil kriteria tersebut dapat di lihat pada tabel 2. Tabel tersebut menjelaskan bahwa kelayakan ekonomi kegiatan penambangan diklasifikasikan menjadi 3 kelas, yaitu tidak layak, kurang layak, dan layak.

Tabel 2. Klasifikasi Kelayakan Ekonomi

\begin{tabular}{ccc}
\hline No. & Total Skor & Klasifikasi \\
\hline 1. & $3,0-5,0$ & Tidak layak \\
2. & $5,1-7,0$ & Kurang layak \\
3. & $7,1-9,0$ & Layak \\
\hline
\end{tabular}

\subsection{Evaluasi Kelayakan Lingkungan}


Kelayakan lingkungan dilakukan secara kuantitatif-empiris. Evaluasi diawali dengan melakukan pelingkupan (scoping) antara kegiatan penambangan dengan rona lingkungan. Hasil pelingkupan akan diketahui 3 (tiga) jenis dampak, yaitu: Dampak Penting Hipotetik (DPH), Dampak Tidak Penting Hipotetik 1 (DTPH 1), dan Dampak Tidak Penting Hipotetik 2 (DTPH 2).

\subsubsection{Klasifikasi Kelayakan Lingkungan}

Hasil pelingkupan antara kegiatan penambangan dengan rona lingkungan digunakan untuk menentukan jumlah dampak dari kegiatan penambangan di tiap titik lokasi. Kemudian jumlah tersebut dikalikan dengan nilai dari setiap dampak yang dihasilkan untuk memperoleh total skor. Nilai dari dampak kegiatan penambangan berbeda-beda sesuai dengan sifat dampak yang dihasilkan. Adapun nilai dari setiap jenis dampak dapat dilihat dari tabel 3. Langkah selanjutnya adalah menentukan klasifikasi kelayakan lingkungan dari total skor yang diperoleh, yang dapat dilihat pada tabel 4 .

Tabel 3. Nilai Dampak Kegiatan Penambangan

\begin{tabular}{ccc}
\hline \multirow{2}{*}{ Parameter } & \multicolumn{2}{c}{ Nilai } \\
& Positif & Negatif \\
\hline DPH & 3 & -1 \\
DTPH 1 & 2 & -1 \\
DTPH 2 & 1 & -1 \\
\hline
\end{tabular}

Tabel 4. Klasifikasi Kelayakan Lingkungan

\begin{tabular}{ccc}
\hline No. & Total Skor & Klasifikasi \\
\hline 1. & $\leq 7$ & Tidak layak \\
2. & $8-21$ & Kurang layak \\
3. & $\geq 22$ & Layak \\
\hline
\end{tabular}

\section{HASIL DAN PEMBAHASAN}

\subsection{Evaluasi Kelayakan Ekonomi}

Kelayakan ekonomi kegiatan penambangan di Kabupaten Sleman menunjukkan hasil yang bervariasi, baik untuk penambangan yang dilakukan di bukit (breksi dan lempung) maupun di sungai (sirtu). Adapun untuk hasil pengharkatan kelayakan ekonomi kegiatan penambangan di bukit bisa dilihat pada Tabel 5 sedangkan kelayakan ekonomi kegiatan penambangan di sungai bisa dilihat pada Tabel 6. Perhitungan ini penting untuk mengetahui keberpihakan terhadap lingkungan (Jackson et al., 2014)

Tabel 5. Kelayakan Ekonomi Kegiatan Penambangan di Bukit

\begin{tabular}{cccccc}
\hline $\begin{array}{c}\text { Titik } \\
\text { Lokasi }\end{array}$ & $\begin{array}{c}\text { Umur } \\
\text { Tambang }\end{array}$ & $\begin{array}{c}\text { Harkat Parameter } \\
\text { Potensi Pasar dan } \\
\text { Pemanfaatan } \\
\text { Bahan Galian }\end{array}$ & BCR & $\begin{array}{c}\text { Total } \\
\text { Harkat }\end{array}$ & Klasifikasi \\
1 & 3 & 2 & 2 & 7 & Kurang layak \\
15 & 1 & 2 & 3 & 6 & Kurang layak \\
16 & 2 & 2 & 3 & 7 & Kurang layak \\
\hline
\end{tabular}




\begin{tabular}{llllll}
\hline 17 & 3 & 2 & 3 & 8 & Layak \\
18 & 3 & 2 & 3 & 8 & Layak \\
19 & 3 & 2 & 3 & 8 & Layak \\
21 & 3 & 2 & 3 & 8 & Layak \\
\hline
\end{tabular}

Keterangan harkat: $1=$ buruk $; 2=$ sedang $; 3=$ baik

Tabel 6. Kelayakan Ekonomi Kegiatan Penambangan di Sungai

\begin{tabular}{cccccc}
\hline $\begin{array}{c}\text { Titik } \\
\text { Lokasi }\end{array}$ & PCPBG & $\begin{array}{c}\text { Harkat Parameter } \\
\text { Potensi Pasar } \\
\text { dan }\end{array}$ & BCR & $\begin{array}{c}\text { Total } \\
\text { Harkat } \\
\text { Pemanfaatan } \\
\text { Bahan Galian }\end{array}$ & Klasifikasi \\
\hline 6 & 3 & 1 & 2 & 6 & \\
8 & 2 & 1 & 2 & 5 & Kuranglayak \\
9 & 2 & 1 & 2 & 4 & Tidak layak \\
11 & 2 & 1 & 2 & 4 & Tidak layak \\
28 & 1 & 1 & 2 & 3 & Tidak layak \\
50 & 2 & 1 & 2 & 4 & Tidak layak \\
51 & 2 & 1 & 2 & 4 & Tidak layak \\
57 & 2 & 1 & 2 & 4 & Tidak layak \\
62 & 2 & 1 & 2 & 4 & Tidak layak \\
72 & 2 & 1 & 2 & 4 & Tidak layak \\
73 & 2 & 1 & 2 & 4 & Tidak layak \\
74 & 3 & 1 & 2 & 6 & Kuranglayak \\
\hline
\end{tabular}

Keterangan harkat: $1=$ buruk ; $2=$ sedang ; $3=$ baik

Berdasarkan Tabel 5 menunjukkan bahwa kelayakan ekonomi kegiatan penambangan di bukit menghasilkan 2 jenis klasifikasi kelayakan ekonomi, yaitu kurang layak dan layak. Titik lokasi yang termasuk kedalam klasifikasi kurang layak adalah titik lokasi 1, 15, dan 16. Secara umum titik lokasi yang tidak layak secara ekonomi disebabkan karena total manfaat dari kegiatan penambangan lebih kecil dibandingkan dengan biaya lingkungan yang harus dikeluarkan. Misalnya untuk titik lokasi 1 pendapatan yang diperoleh dari kegiatan penambangan ini hanya senilai Rp 10.800.000 sedangkan biaya lingkungan yang seharusnya dikeluarkan untuk mengelola bekas galian tambang lebih besar dari Rp 10.800.000. Faktor lain yang membuat titik lokasi 1 tidak layak secara ekonomi adalah potensi pasar yang masuk kedalam kelas sedang. Hal ini disebabkan karena produk tambang hanya dibutuhkan atau dipasarkan di sekitar Kabupaten Sleman sehingga jangkauan pasar tidak terlalu luas. Potensi sedang mengindikasikan bahwa permintaan produk tambang dimasa depan tidak terlalu tinggi karena ada produk serupa di daerah lain ataupun terdapat produk substitusi batu breksi sebagai bahan bangunan.

Titik lokasi yang termasuk kedalam klasifikasi layak untuk kegiatan penambangan di bukit berdasarkan Tabel 5. adalah titik lokasi 17, 18, 19, dan 21. Secara umum titik lokasi yang layak secara ekonomi memiliki kondisi yang baik pada setiap parameter. Misalnya untuk titik lokasi 17 layak dikarenakan cadangan tertambang masih banyak dengan tingkat produksi tidak terlalu tinggi 
sehingga umur tambang masuk kedalam kategori panjang. Jumlah produksi yang diperoleh titik ini 60 rit per bulan. Potensi pasar titik ini masuk dalam kategori sedang, karena tingkat permintaan produk cukup tinggi dengan daerah pemasaran sampai di luar DIY. Potensi pasar juga dipengaruhi oleh kualitas produk tambang yang cukup baik sebagai bahan baku pembuatan bata merah dan bahan campuran untuk genteng. Dari aspek BCR memiliki kategori baik karena manfaat kegiatan penambangan masih mampu untuk menutupi biaya lingkungan yang digunakan untuk memperbaiki kualitas lingkungan seperti perbaikan jalan. Adapun manfaat yang diperoleh sebesar Rp 6.600.000 per bulan.

Evaluasi kelayakan ekonomi selanjutnya adalah untuk kegiatan penambangan di sungai. Berdasarkan Tabel 6. menunjukkan bahwa terdapat 10 titik lokasi penambangan termasuk kedalam klasifikasi tidak layak dan 2 titik lokasi termasuk kedalam klasifikasi kurang layak. Secara umum ketidaklayakan ekonomi penambangan di sungai disebabkan oleh cadangan tertambang kecil dan tingkat produksi cukup banyak, sehingga PCPBG pendek. Potensi pasar juga termasuk kedalam klasifikasi rendan karena daerah pemasaran hanya didaerah sekitar lokasi penambangan. Dari aspek BCR memiliki kategori sedang (benefit = cost) yang artinya manfaat pertambangan hanya mampu atau habis jika digunakan untuk memperbaiki kualitas lingkungan yang rusak akibat kegiatan penambangan pasir, misal perbaikan jalan dan upaya pengelolaan bakas galian yang ditinggalkan (Suparmoko dan Ratnaningsih, 2012) .

Hasil evaluasi kelayakan ekonomi kegiatan penambangan di Kabupaten Sleman dapat disimpulkan bahwa sebagian besar titik lokasi yang tidak layak adalah titik lokasi penambangan pasir di sungai. Dimana penambangan tersebut sangat bergantung dengan kondisi alam khususnya bencana letusan Gunung Api Merapi. Bencana tersebut menjadi supply material yang akan ditambang oleh masyarakat. Letusan gunung api Merapi terakhir terjadi pada tahun 2010 dan sejak saat itu kegiatan penambangan dilakukan secara aktif sehingga untuk saat ini cadangan tertambang yang ada disungai di Kabupaten Sleman mayoritas menunjukkan jumlah yang sedikit dan belum ada kegiatan pengelolaan lingkungan akibat kegiatan penambangan tersebut. Kondisi tersebut yang mempengaruhi kegiatan penambangan menjadi tidak layak secara ekonomi. Akan tetapi kondisi ini bisa berubah menjadi layak jika cadangan tertambang menjadi banyak dan ada pengelolaan lingkungan akibat kegiatan penambangan tersebut.

\subsection{Evaluasi Kelayakan lingkungan}

Kelayakan lingkungan kegiatan penambangan di Kabupaten Sleman ditentukan dari jumlah dampak yang ditimbulkan akibat kegiatan penambangan tersebut. Dampak tersebut adalah dampak yang berkaitan dengan lingkungan, baik secara langsung maupun tidak langsung. Jenis dampak yang 
digunakan sebagai parameter dalam menentukan kelayakan lingkungan ada 3, yaitu Dampak Penting Hipotetik (DPH), Dampak Tidak Penting Hipotetik 1 (DTPH 1), dan Dampak Tidak Penting Hipotetik 2 (DTPH 2). Setiap dampak yang dihitung tersebut memiliki nilai negatif dan positif. Adapun dasar evaluasi yang digunakan untuk menentukan kelayakan lingkungan adalah semakin banyak dampak negatif yang dihasilkan dibandingkan dengan dampak positif maka kegiatan penambangan tidak memberikan keuntungan bagi lingkungan (Suparmoko dan Ratnaningsih, 2011). Oleh karena itu, kegiatan penambangan menjadi kurang layak bahkan tidak layak untuk ditetapkan sebagai WPR dari aspek kelayakan lingkungan. Adapun hasil kelayakan lingkungan dapat dilihat pada Tabel 3.3.

\begin{tabular}{|c|c|c|c|c|c|c|}
\hline \multirow[t]{2}{*}{ No. } & \multirow{2}{*}{$\begin{array}{c}\text { Titik } \\
\text { Lokasi }\end{array}$} & \multicolumn{3}{|c|}{ Jumlah Nilai } & \multirow{2}{*}{$\begin{array}{c}\text { Total } \\
\text { Harkat }\end{array}$} & \multirow{2}{*}{ Klasifikasi } \\
\hline & & DPH & DTPH 1 & DTPH 2 & & \\
\hline 1 & 1 & 1 & -2 & -1 & -2 & tidak layak \\
\hline 2 & 6 & 4 & -1 & 0 & 3 & tidak layak \\
\hline 3 & 8 & 4 & -1 & 0 & 3 & tidak layak \\
\hline 4 & 9 & 5 & -1 & 0 & 4 & tidak layak \\
\hline 5 & 11 & 5 & -2 & 0 & 3 & tidak layak \\
\hline 6 & 15 & 13 & 6 & 0 & 19 & kurang layak \\
\hline 7 & 16 & 27 & 6 & 0 & 33 & layak \\
\hline 8 & 17 & 29 & -2 & -1 & 26 & layak \\
\hline 9 & 18 & 17 & 0 & -1 & 16 & kurang layak \\
\hline 10 & 19 & 29 & 3 & -1 & 31 & layak \\
\hline 11 & 21 & 0 & -5 & -1 & -6 & tidak layak \\
\hline 12 & 28 & 4 & 0 & 0 & 4 & tidak layak \\
\hline 13 & 50 & 6 & 6 & 0 & 12 & kurang layak \\
\hline 14 & 51 & 7 & 8 & 0 & 15 & kurang layak \\
\hline 15 & 57 & 4 & -1 & 0 & 3 & tidak layak \\
\hline 16 & 62 & 4 & -1 & 0 & 3 & tidak layak \\
\hline 17 & 72 & 4 & -1 & 0 & 3 & tidak layak \\
\hline 18 & 73 & 3 & 0 & 0 & 3 & tidak layak \\
\hline 19 & 74 & 3 & -1 & 0 & 2 & tidak layak \\
\hline
\end{tabular}

Keterangan Dampak : DPH = Dampak Penting Hipotetik, DTPH 1 = Dampak Tidak Penting Hipotetik 1, Dampak Tidak Penting Hipotetik 2 (DTPH 2)

Berdasarkan Tabel 7 dapat dijelaskan bahwa dari 19 titik lokasi penambangan yang ada di Kabupaten Sleman terdapat 12 titik lokasi (1, 6, 8, 9, 11, 21, 28, 57, 62, 72, 73, dan 74) yang termasuk ke dalam klasifikasi tidak layak. Sedangkan 4 titik lokasi $(15,18,50$, dan 51) dan 3 titik lokasi lainnya (16, 17, dan 19) termasuk kedalam klasifikasi kurang layak dan layak. Klasifikasi pertama untuk kelayakan lingkungan adalah tidak layak. Terdapat 12 titik lokasi yang termasuk kedalam klasifikasi tidak layak. Banyaknya titik lokasi yang tidak layak disebabkan karena dampak 
negatif yang dihasilkan lebih banyak dibandingkan dengan dampak positifnya. Sebagai contoh adalah titik lokasi no.1, titik tersebut adalah titik lokasi penambangan batu breksi yang berada di Prambanan. Kegiatan penambangan tersebut menghasilkan DPH, DTPH 1 dan DTPH 2 yang bersifat negatif lebih banyak dibandingkan dengan yang bersifat positif. Adapun dampak negatif yang dihasilkan akibat kegiatan penambangan breksi antara lain: terjadi perubahan bentuk medan, terjadi erosi, terjadi penurunan kerapatan tutupan vegetasi, peningkatan risiko K3, kerusakan jalan umum, perubahan penggunaan lahan, peningkatan kadar debu dan terjadi kebisingan. Sedangkan dampak positif yang dihasilkan adalah menciptakan kesempatan kerja dan peluang usaha serta adanya peningkatan pendapatan masyarakat akibat kesempatan kerja yang ditimbulkan tersebut. Dampak positif kegiatan penambangan ini hanya dirasakan oleh sebagian kecil masyarakat setempat, yaitu masyarakat yang bekerja sebagai tenaga penambang sejumlah 8 orang. Sedangkan dampak negatif yang dihasilkan dirasakan oleh sebagaian besar masyarakat yang berada di sekitar lokasi penambangan. Kondisi ini juga terjadi pada titik lokasi lainnya yang termasuk kedalam klasifikasi tidak layak dari aspek lingkungan, apalagi jika kegiatan penambangan dilakukan oleh satu keluarga, seperti di titik lokasi no.21. Dampak positif sebagai peningkat pendapatan masyarakat dititik tersebut hanya dirasakan oleh keluarga yang memiliki lahan penambangan, karena yang bekerja sebagai pelaku penambangan adalah keluarga pemilik lahan dan hanya sedikit melibatkan masyarakat sekitar. Padahal masyarakat lainnya merasakan dampak negatif yang dihasilkan dari kegiatan penambangan, khususnya pada tahap pengangkutan/transportasi hasil galian. Adapun contoh dampak negatif yang dirasakan oleh masyarakat disekitar lokasi penambangan adalah jalan umum menjadi rusak serta terjadi peningkatan kadar debu dan kebisingan. Adanya dampak negatif yang tidak segera dikelola oleh pelaku penambangan juga semakin menambah dampak yang ditimbulkan, yaitu memicu konflik antar warga. Dengan demikian, banyaknya dampak negatif yang muncul semakin membuat kegiatan penambangan tidak layak untuk ditetapkan sebagai WPR.

Klasifikasi kedua adalah kurang layak dari aspek lingkungan. Terdapat 4 titik lokasi penambangan yang termasuk kedalam klasifikasi tersebut. Kondisi di titik ini sedikit lebih baik daripada 12 titik lokasi sebelumnya. Kegiatan penambangan yang termasuk kedalam klasifikasi kurang layak adalah kegiatan penambangan lempung (titik 15 dan 18) dan penambangan pasir (titik 50 dan 51). Kegiatan penambangan pasir dan lempung memiliki dampak positif dan dampak negatif dengan jumlah yang hampir sama banyaknya sehingga harkat yang dihasilkan kecil. Dampak positif dari kegiatan penambangan lempung di titik lokasi no.15 di dukung adanya kegiatan perbaikan lingkungan dan pemanfaatan lahan bekas galian penambangan. Di titik lokasi ini lubang bekas 
galian penambangan dijadikan sebagai kolam ikan sehingga memberikan dampak positif bagi lingkungan, seperti perbaikan iklim mikro, penurunan run off, membaiknya kondisi flora fauna sekitar, menambah peluang usaha masyarakat, dan mengubah persepsi masyarakat menjadi lebih baik terhadap kegiatan penambangan.

Klasifikasi ketiga kelayakan lingkungan adalah layak untuk ditetapkan sebagai WPR dari aspek lingkungan. Terdapat 3 titik lokasi penambangan dengan jenis bahan tambang berupa lempung. Kegiatan penambangan di tiga lokasi ini layak karena jumlah dampak positif lebih banyak dibandingkan dengan jumlah negatifnya. Kondisi ini jauh lebih baik daripada 16 titik lokasi lainnya. Kegiatan penambangan yang termasuk kedalam klasifikasi layak ini semuanya memiliki rencana pasca penambangan dan sudah mulai dilakukan terhadap lahan bekas penambangan yang ada disekitarnya. Adapun rencana pasca tambang yang akan dilakukan adalah menjadikan perumahan dan kegiatan pasca penambangan yang sudah dilakukan adalah revegetasi. Dari kegiatan revegetasi yang sudah dilakukan maka dapat menimbulkan dampak positif bagi lingkungan, seperti: penurunan kadar debu, perbaikan iklim mikro, penurunan run off, membaiknya kondisi flora-fauna sekitar, peningkatan kesehatan masyarakat, peningkatan kualitas dan kuantitas airtanah, serta mengubah persepsi masyarakat menjadi lebih baik terhadap kegiatan penambangan.

Dengan demikian dapat disimpulkan bahwa titik lokasi penambangan yang memiliki kelayakan secara lingkungan didukung oleh adanya kegiatan pasca penambangan yang direncanakan ataupun yang sudah dilakukan memerlukan metode perencanaan yang matang (Herman, 2006). Dengan adanya kegiatan pasca penambangan maka pelaku kegiatan penambangan sudah memikirkan kondisi lingkungan sekitar. Pelaku penambangan tidak saja mengambil keuntungan secara ekonomi melainkan sudah ikut berpartisipasi dalam memperbaiki lingkungan akibat kegiatan penambangan yang sudah dilakukan. Oleh karena itu, semakin baik rencana pasca penambangan ataupun kegiatan pasca penambangan yang sudah dilakukan maka dampak positif yang diberikan bagi lingkungan semakin banyak sehingga kegiatan penambangan semakin layak untuk ditetapkan sebagai WPR.

\section{KESIMPULAN}

Kegiatan pertambangan rakyat yang ada di Kabupaten Sleman memiliki hasil kelayakan ekonomi tidak layak (10 titik lokasi), kurang layak (5 titik lokasi) dan layak (4 titik lokasi). Sebagian besar titik lokasi yang tidak layak secara ekonomi adalah titik lokasi penambangan pasir di sungai. Secara umum titik lokasi yang tidak layak dari aspek ekonomi disebabkan karena total manfaat dari kegiatan penambangan lebih kecil dibandingkan dengan biaya lingkungan yang harus dikeluarkan. Sedangkan untuk kelayakan lingkungan penambangan rakyat di Kabupaten Sleman memiliki hasil tidak layak (12 titik lokasi), kurang layak (4 titik lokasi) dan layak (3 titik lokasi). Kelayakan 
lingkungan penambangan rakyat di Kabupaten Sleman dipengaruhi oleh jumlah dampak yang dihasilkan, baik yang bersifat positif maupun negatif. Semakin banyak dampak positif yang dihasilkan dan disertai oleh upaya pengelolaan lingkungan akibat dampak yang ditimbulkan maka kegiatan pertambangan akan semakin layak secara lingkungan.

\section{DAFTAR PUSTAKA}

Astuti F, A., (2016), Valuasi Ekonomi Limbah Cair Industri Gula dan Spiritus Di Kecamatan Kasihan, Kabupaten Bantul, Propinsi DIY, Jurnal Sains dan Teknologi Lingkungan, Vol. 8 No. 1 Hal. 21-35.

Dinas Pertambangan Kabupaten Sleman, (2000), Pemetaan Bahan Galian Golongan C di Kecamatan Turi, Tempel dan Pakem, Kabupaten Sleman, Daerah Istimewa Yogyakarta.

Fauzi, A, (2004), Ekonomi Sumberdaya Alam dan Lingkungan, Gramedia Pustaka Utama, Jakarta.

Herman, D, Z, (2006), Tinjauan terhadap tailing mengandung unsur pencemar Arsen (As), Merkuri $(\mathrm{Hg})$, Timbal $(\mathrm{Pb})$, dan Kadmium $(\mathrm{Cd})$ dari sisa pengolahan bijih logam, Jurnal Geologi Indonesia, Vol.1 No. 1, hal. 31-36.

Jackson S, Marcus F, and Scheepers K., (2014), The Use of Replacement Cost Method to Assess and Manage The Impacts of Water Resource Development on Australian Indigenous Customary Economies. Journal of Environmental Management. Volume 135. Hal. 100109.

Larasati R, Setyono P, Sambowo K, A., (2012), Valuasi Ekonomi Eksternalitas Penggunaan Merkuri Pada Pertambangan Emas Rakyat Dan Peran Pemerintah Daerah Mengatasi Pencemaran Merkuri (Studi Kasus Pertambangan Emas Rakyat di Kecamatan Kokap Kulon Progo), Jurnal Ekosains, Vol. 4 No. 1, Hal. 48-63.

Noor, D, (2006), Geologi Lingkungan Edisi Pertama, Penerbit Graha Ilmu, Yogyakarta.

Suparmoko, M dan Ratnaningsih M., (2011), Ekonomi Lingkungan Edisi Kedua BPFE. Yogyakarta.

Suparmoko, M dan Ratnaningsih M, (2012), Ekonomika Lingkungan, BPFE Yogyakarta. 